\title{
$>$ EDITORIAL
}

El presente número de la revista De Signos y Sentidos se organiza en torno a tres artículos que abordan el fenómeno religioso desde una perspectiva discursiva. El trabajo de Martín Acebal analiza un corpus de homilías católicas pronunciadas en iglesias de la ciudad de Santa Fe. El texto indaga en una serie de estrategias discursivas a partir de un enfoque metodológico basado en el estudio de casos. El artículo de Pablo Piteo se centra en el análisis de la metáfora en la encíclica Laudato si' como eje vertebrador de la interdiscursividad que configura este texto como un texto polifónico. El trabajo de Juan Pablo Giordano indaga en los desplazamientos del sentido social sobre un eje que va de lo sagrado a lo profano y, a través de éste, el modo en que Marx asume el análisis de representaciones que sacralizan el lazo social.

Finalmente, se proponen dos reseñas sobre investigaciones que abordan las relaciones entre catolicismo, sociedad y política en la Argentina moderna. Los trabajos presentados pretenden dar cuenta de las prácticas religiosas como prácticas sociales, en tanto pueden ser estudiadas como prácticas discursivas. 